China Perspectives

50 | november- december 2003

Varia

\title{
The Sword of the Halhala River
}

A short story by Xiao Kefan

\section{Xiao Kefan}

\section{(2) OpenEdition}

\section{Journals}

Édition électronique

URL : http://journals.openedition.org/chinaperspectives/777

DOI : 10.4000/chinaperspectives. 777

ISSN : 1996-4617

Éditeur

Centre d'étude français sur la Chine contemporaine

Édition imprimée

Date de publication : 1 décembre 2003

ISSN : 2070-3449

\section{Référence électronique}

Xiao Kefan, «The Sword of the Halhala River », China Perspectives [En ligne], 50 | november- december 2003, mis en ligne le 20 juin 2007, consulté le 28 octobre 2019. URL : http://journals.openedition.org/ chinaperspectives/777; DOI : 10.4000/chinaperspectives.777

Ce document a été généré automatiquement le 28 octobre 2019

(c) All rights reserved 


\title{
The Sword of the Halhala River
}

\author{
A short story by Xiao Kefan
}

\section{Xiao Kefan}

\section{NOTE DE L'ÉDITEUR}

This short story was first published in Shiyue, 2003/1

Translated from the Chinese original by Caroline Mason

1 The man was climbing Nameless Hill, on the bank of the Halhala River. It wasn't particularly high-more like a dwarf among hills, really-but even so, climbing it was hard work, and he was panting. From the corner of his eye he glimpsed drops of his sweat falling into the thick grass and immediately evaporating. Several times on his journey he had felt so discouraged that he would have liked to have given the whole thing up, but he couldn't quite make himself do it, so he struggled on, swearing loudly as he went. He wasn't swearing at the hill for being so high-hardly a fault in a hill after all-no, he was cursing himself for his failing strength. The energy he used to have had completely disappeared and now he couldn't even manage to climb Nameless Hill. When a man got to fifty he was past his prime, and didn't have as much vitality as he used to: it was like the sun losing strength after midday. He pulled up some grass as he walked along, stuffed it into his mouth and chewed vigorously, with such exaggerated movements of his jaw that he looked as if he were imitating an old horse chomping its hay. Even the grass tasted different these days and had lost its old fragrance. Everything seemed to have changed, the only thing which hadn't was the green-black Halhala River, which kept flowing along and never turned back, whatever happened. That's how an Inner Mongolian river should be! It cheered him up to think of that. The knife-scar on the left side of his face was still a vivid purple, a colour he liked. People can't just change their colouring when they feel like it, and if his scar was purple, so be it.

2 A dark cloud floated overhead, rudely blotting out the sun, and with the sudden loss of brightness Nameless Hill appeared very desolate indeed. He knew that this was likely to 
have a depressing effect, not just on the grass, but on people too, so he summoned all his energy and with a great bellow made a dash for the top of the hill. When he got there, his breath was coming in loud gasps, and he distinctly felt the dark cloud brush his shoulders as it slipped menacingly away in the direction of the valley. As the cloud passed overhead, the water of the winding Halhala River changed colour. How dull and murky the river looked now, like the blade of a rusty knife! The lush pastures of the valley were dotted with bright, multi-coloured tourist tents, which looked from far away like the gaudy mushrooms in children's fairy-tales. Yes, they were tents, not yurts, he thought to himself, because they belonged to Zhang Shu. Zhang had come to this border region as a "Red Heart" ${ }^{1}$ over thirty years ago, settled down and never returned to the city. Over time he had become a "big belly"-the local slang name for the rich people known as dakuan in Beijing-by exploiting the natural advantages of the river. Every year, in the summer season, crowds of dakuan would come to the Halhala valley from the far-off big cities, flocking to spend their holidays in the fake yurts owned by Zhang Shu's tour company. The used condoms they left behind when they went home were the only rubber articles to be found in the area. The local kids, thinking they were shrivelled party balloons, would put them to their lips and try to blow them up, and you'd keep hearing muffled popping sounds as they exploded. People said Zhang shu used to chuckle happily whenever he heard these noises.

3 The man was wearing a crumpled, brownish jacket, wide military-type khaki trousers, and shabby brown leather boots-the sort of outfit any typical migrant worker wears these days. As he stood on top of the hill, looking down at the holiday village and its brightly-coloured tents dotted all over the valley, his feelings were very mixed. He remembered how, some twenty years earlier, the young men in the "Educated Youth Brigade" had all slept on the same large kang, with him at one end and Zhang Shu at the other. And now Zhang Shu was the richest man in the area and had even restored the three mud huts their brigade used to live in and turned them into the "Former Residence of Zhang Shu", where the first thing you saw as you walked into the courtyard was a horizontal plaque with those sparkling golden characters written on it, the work of the famous calligrapher Mu Feng.

4 He felt a great sense of inferiority. In spite of the fact that everyone along the banks of the Halhala River knew his name, and the handy piča $q^{2}$ knives he made were so popular with the tourists, and although he would be assured of a warm welcome and cups of milky tea for a hundred miles around, he still felt that all that counted for nothing. "When I first came here", he once again ran through his personal history in his mind, "I joined a production team, but later on I went back to the city. I got a job in a factory, in the blacksmith's workshop, and several years running won the title of 'Outstanding Production Worker', but then I was laid off, and my wife ran away with another man". Blacksmiths weren't needed in the big cities any more-he had been forced to admit that he was surplus to requirements. He was fifty now, and here he was again, returning alone to the banks of the Halhala, the river which had witnessed his youth, and earning his living by working metal in a forge.

5 A narrow path snaked down into the mountain valley, which, depending on how you looked at it, was of course also the river valley. The Halhala meandered back and forth, impressing a memory of the hills on the river, and of the river on the hills. The hills and the river will never forget each other, he thought-the creature with the worst memory is man, who remembers nothing but money and women. As he was thinking 
this, he noticed that the dark cloud had moved away, not after all as threatening as it had appeared. The scene in the valley below was sparkling in the sunshine again, as if nothing had happened. The good old rock-solid Halhala valley! He followed the narrow path downhill. When you're climbing a hill all you need is to brace yourself for one last vigorous effort and you can reach the top-but when you're going downhill, it gets harder. That was how Li Liru had died, when she stumbled and fell.

More than thirty of the brightly-coloured tents were scattered around on the flowerstudded river-bank. He could smell the scent of the wild roses, coming up to greet him, a scent so strong it took him by surprise. The tourists were always bowled over by it. The wild roses of the Halhala valley have a murderous fragrance, they are flowers ${ }^{3}$ which kill without compunction. Nearly all the "big bellies" staying in the holiday village would happily suffer death by rose-perfume, it appeared-or at any rate, that's what they sang in their colourful tents, though not really to express their feelings so much as to help them digest the venison in their stomachs.

Walking down into the small hollow at the foot of the hill, the man strode past the tents, one after the other, and was filled with resentment. He was acutely aware that this holiday village belonged to the company owned by the prosperous Zhang Shu, and that he was merely a blacksmith who made Halhala knives. The scent of the wild roses in the valley came to greet him, mixed with the smell of the French perfumes worn by the tourists. He smiled bitterly as he walked towards the setting sun, feeling there was nothing he could do to change the situation.

8 At dusk, in the distance, bonfires were being lit-signifying the blazing impatience felt by the "big bellies", who had been waiting eagerly for the night life to begin. For them, the days were far too long. Dragging his elongated shadow behind him, the man walked towards a worn and shabby yurt which clearly wasn't the sort of place where the rich men drank, because they didn't serve brandy or any other expensive spirits there. The only drink on offer was the wonderful liquor, brewed with water from the Halhala River, which they called 'fire-knife'. He was never quite sure why it was called 'fire-knife ', rather than 'firewater': liquor wasn't like a knife, was it? Though sometimes, he thought to himself, liquor was indeed a knife, and sometimes men were its whetstones.

When he went inside the yurt he found several men drinking 'fire-knife'. They all appeared very relaxed-the alcohol tasted mellow and had integrity. Yes, you could say that some kinds of alcohol, like some men, have moral integrity. He greeted the men, all of whom he knew to be small businessmen. They recognised him too-to them he was 'Knife Man'. He knew, of course, that that was what people round here called him. Though he produced all sorts of metal objects, including horseshoes, in his forge on the bank of the Halhala River, the most well-known were the various kinds of knives he made. The fact that he always quenched them at night conferred a certain air of mystery on him.

The drinkers in the yurt moved up and made room for him, asking him to sit down and join them. It was dark now, but his mood was much better, and he reached out his hands for a big bowl of the liquor and gulped down a mouthful of it. Yes, that was good stuff, it went straight to the bottom of your heart, without stopping on the way. Just then, things started to liven up outside the yurt, and he realised that the singer Ma Touqin had arrived, and with her the song "Paradise", which everyone here, good and bad alike, could sing. 
11 "A blue, blue sky, a turquoise lake, green, green plains...". He listened with his eyes closed, already feeling the effects of the alcohol. "Pure white sheep, galloping steedsand you, so very beautiful!" At the end of the song, he opened his eyes wide and addressed himself loudly to the singer outside the yurt. "And Halhala knives, as well", he said.

12 No response came from outside the yurt, but inside several of the drinkers laughed. One of them shook his head. "I can't agree with that, there won't be any knives in Paradise". Yes, thought the man, he's right. Paradise is so perfect that there'll be no use for knives. The thought made him conscious once more of his own inferiority. If there was no use for knives in Paradise, would a blacksmith like him be able to get in? No. He bowed his head and drank, saying nothing more.

Silently, several young girls came into the yurt. The men brightened up at once, their faces shining with delight, and almost fell over themselves to make them welcome. They made space for them and asked them to sit down. The man realised that this was all part of the service provided by Zhang Shu's tour company-the girls were hostesses and were supposed to drink with them. He wasn't used to this sort of occasion and just kept drinking, his head down.

As the girl beside him reached out to re-fill his glass, he noticed the iron bracelet she was wearing on her wrist. In astonishment, he turned to face her, and asked, "Where did you get that bracelet?". She had a thin face and pretty, slanting eyes-she looked as if she never had enough to eat. He grabbed hold of her fragile little arm and looked hard at the bracelet. The girl, growing alarmed, removed her arm from his grasp, but he kept asking her where she got the bracelet. She jumped up and ran out of the yurt. The other men roared with laughter, which obviously meant "Knife Man likes the girls, but he hasn't got the nerve to do anything about it!". His face darkened, and he tried to explain that the bracelet was a truly fine piece of craftsmanship, but the men were still laughing at him, all of them talking at once and encouraging him to run after her. Furious, he slammed his large bowl down on the small table. The atmosphere in the yurt had suddenly become very hostile. One of the men, looking nervous, instinctively reached down and felt for the knife concealed in his boot.

The blacksmith gave a sudden, scornful laugh and said, "You couldn't use that knife of yours for killing anyone, it's only fit for slaughtering chickens!" None of the men dared to laugh this time. They were all looking at the purple scar on his left cheek. It was very nearly the same colour as the wild roses in the Halhala valley. "All I wanted", he told them, "was to know who made that iron bracelet she was wearing!" Timidly, one of them whispered that the girl's name was Xiao Qing, that she had lost her mother at an early age and had had a very hard life. The blacksmith said nothing.

At that moment, Zhang Shu came into the yurt, laughing loudly, his small eyes glittering from the effects of alcohol. Behind his corpulent figure appeared two burly fellows who were obviously his bodyguards. Zhang greeted the blacksmith, walked straight over to where he was sitting and tapped him on the shoulder. "Mr Mu wants to see you, Knife Man". He looked up: “Who's he?". Zhang told him, "He's a 'big belly' from the city, and he wants to see you-now!"

17 The yurt went quiet. The other fellows stood up and, one by one, slipped outside. He asked Zhang what had made them leave so fast, and Zhang chuckled. "When small 
animals see a large animal, they generally get out quick!" The blacksmith asked who the large animal might be, and Zhang replied, "Mr Mu, of course."

He shook his head and said he wouldn't go. Zhang's face flushed with annoyance. "Why was it you came to the Halhala valley? To make things to sell to people and earn some money, isn't that right? Well, if you want to get rich, go and see $\mathrm{Mr} \mathrm{Mu}$ at once!"

Weakening at the mention of money, the blacksmith reached out, picked up the bowl and put it inside his shirt. He got slowly to his feet: "Come on, then". Zhang chuckled and congratulated him on being so sensible. He followed Zhang out of the shabby yurt and saw in the distance the flames of the bonfires leaping skywards. The fires seemed somehow to have affected the scent of the roses in the night air, and their perfume now had a kind of rankness to it.

20 Watching the far-off bonfires, he followed Zhang shu to a large red tent, taller than all of the others. One of the bodyguards went inside to announce their arrival, the other stood sentinel outside the opening and ordered the blacksmith to hand over the bowl he had tucked inside his shirt. He protested-“It's just a begging-bowl, that's all!"-but Zhang whispered to him that that was the rule here, and anyone who came to see $\mathrm{Mr}$ $\mathrm{Mu}$ had to be checked, for security purposes. He frowned, and a rush of blood to the scar on his left cheek flushed it an even deeper purple.

The bodyguard who had gone into the tent to announce their arrival now reappeared and gestured to the blacksmith that he should go in. Zhang Shu shot him a look, clearly a warning: when a small animal has an audience with a large one, it has to be timid and on its best behaviour, otherwise it will be gobbled up. The blacksmith betrayed no signs of anxiety-after all, why would a blacksmith need to panic? He calmly pulled aside the curtain over the entrance and went into the tent. In the dim light inside, the first thing he saw was a man lying in a huge leather armchair; then he noticed that the man's movements were very stiff, which reminded him of some kind of living corpse. So this creature was $\mathrm{Mr} \mathrm{Mu}$, was it? He thought it rather ludicrous that a "big belly" from the big city should turn out to look like this.

Still reclining on the chair, $\mathrm{Mr} \mathrm{Mu}$ pointed at a wooden stool and motioned him to sit down. He did as he was told, and in the dim light took the opportunity to look at $\mathrm{Mr}$ Mu's shrivelled hands. Well, well! So this was what a rich man looked like! What a strange animal-just skin and bones!

The skinny animal finally managed to reach a sitting position. His silvery hair and piercing eyes reminded the blacksmith so much of his father that he almost cried out. Before his father had died of stomach cancer at the age of seventy-three, he had had a head of silvery hair just like this, and the same piercing gaze, the same emaciated body. The only difference was that his father had been poor, and $\mathrm{Mr} \mathrm{Mu}$ was rich. Wealth and poverty, what a world of difference there was between the two.

The rich man spoke, in a very pleasant voice. He asked the blacksmith to make him a sword, six feet long and with a blade four inches wide. Not in the Tibetan style, or the Inner Mongolian or Arab styles, but a magic sword of the sort used during the Han dynasty to keep demons away from people's houses.

"With a cow-hide scabbard, Mr Mu?" Mr Mu, his face expressionless, told him that once the sword was finished he would go to Xishuangbanna, in Yunnan, and have a scabbard made for it out of python skin. As he said this, he slowly got up from the leather chair and shook a wizened finger under the blacksmith's nose: "Mind you put every ounce of 
your skill into it", he said, "And when it's finished I will pay you 8,888 yuan 8 mao and 8 fen"4.

That was a lot of money! He jumped to his feet, with loud expressions of gratitude. $\mathrm{Mr}$ Mu was giving him further instructions: "The name of the sword is to be 'Golden Boy', and you must engrave this name on the blade. Bring it to me in three days time-and be sure you make a good job of it".

The blacksmith promised he would. Mr Mu asked if he knew anything about the "Jade Maiden" ${ }^{5}$, and he shook his head blankly. No, he knew nothing. With a smile, Mr Mu dismissed him.

Obediently, the blacksmith turned round and left the red tent. Outside, Zhang Shu hurried over to greet him. He was looking distinctly nervous, but a look of relief crossed his face when the blacksmith told him that $\mathrm{Mr} \mathrm{Mu}$ had commissioned him to make a six-foot long, four-inch wide sword, to be called "Golden Boy". "Wonderful! If there's going to be a 'Golden Boy' that means there'll have to be a 'Jade Maiden!"'

The blacksmith didn't know what the "Jade Maiden" was, all he knew was that he had been commissioned to make the "Golden Boy". He set off into the darkness of the night, heading for his forge beside the river. "Well now! 8,888 yuan 8 mao and 8 fen! The reason why I left the city and came all this way to the Halhala valley was to set up my forge and earn some money, that's true. But Mr Mu is no ordinary man if he's willing to pay all that money just for a sword to keep the demons away from his home. That's nearly 9,000 yuan!" That sort of gesture proved that $\mathrm{Mr} \mathrm{Mu}$ really was a "big belly" from the big city.

He was sitting pensively on a large rock on the river-bank, looking into the darkness of the night, when Dumb Boy appeared soundlessly at his side and like a good fairy lit a small fire. The flames illuminated the ceaselessly flowing waters of the Halhala River and also the scar on the blacksmith's left cheek, that purple scar of his which now twitched a couple of times in the firelight.

Nobody knew where the young lad they called Dumb Boy came from. He behaved very strangely, like an owl-he was never seen in the day, and only ever appeared at night. Although he was dumb, he always seemed to be trying to say something, opening his mouth but never managing to make any sounds. The blacksmith had worked out that the lad wanted him to teach him how to work a forge and make things out of metal, and after all why not? It might well be a suitable job for him, because blacksmiths didn't need to be able to speak.

The fire was burning brighter and brighter. Dumb Boy handed him a bottle of liquor in the light of the flames-it was 'fire-knife'. He took it from him, opened it with his teeth and swallowed a mouthful. He was feeling content, and knew that his good humour was a direct result of being offered all that money-8,888 yuan 8 mao and $8 \mathrm{fen}$. He gulped down some more of the liquor. Dumb Boy lifted his head and looked intently into the night sky, as if he knew what the blacksmith was thinking.

The blacksmith explained to Dumb Boy in sign language that he had been given a very important commission-he had been asked to make a sword for a "big belly" from the far-off big city. It was to be called "Golden Boy", and was to be four inches wide and six feet long. When the lad understood what he meant, he gesticulated back, signalling that a request like that made him feel uneasy. The fire was dying down. He put his hand up to feel the scar on his face, and with a smile told the boy that he had a fine piece of steel 
hidden away in a good spot, and now that it was dark and there was nobody around it would be a good time to go and dig it up. The boy immediately ran off and came back with a spade, which he handed to him.

By now the fire had gone out, and the night seemed even more dense. He shouldered the shovel and walked down to the foot of Nameless Hill, where there was a wood of black pines, with Dumb Boy hard on his heels.

The starlight was very faint. They walked a long way in among the black pines. This place, which had once been known as "Educated Youths' Wood", had since then been indiscriminately deforested: most of the trees had been felled for timber, and the place was a chaos of tree-stumps. His block of fine steel was buried at the foot of a big pine. He hurried over to the tree with the shovel, and started to dig. How it brought back the past, which had faded in his mind! All those years ago, when they were planting the trees, he and Li Liru had secretly fallen in love, and that same tree had witnessed their first kiss.

36 The digging was making him breathless. At last there was a clang, as the spade struck something hard. He squatted down to feel around in the hole-yes! His fine piece of self-hardening manganese steel was still there, and even after being buried for six months it showed no signs of rust.

Dumb Boy bent over and lifted it up, swung it onto his shoulder with a grunt and turned away. The sky was growing lighter by this time, and he ran like the wind, the steel on his shoulder, emerging from the pine-wood well ahead of the blacksmith, who was feeling old and tired. Back in the old days, when they were planting the "Educated Youths' Wood" he'd been able to move fast even with a whole bundle of saplings on his shoulder. He had walked tall and straight back then, and never got breathless. He turned to look back at "their" pine, now so tall, and was filled with sadness. Time flies so fast-it was already twenty-six years since Li Liru's death.

Dumb Boy was far ahead now, and there was no hope of catching up with him. All of a sudden, and to his great surprise, the blacksmith noticed what he took to be a rock on the side of the hill, a rock he had never seen before. The slope wasn't very steep, but he was sweating profusely as he climbed towards it. Little by little he made out that it wasn't a rock after all, it was a person-and as he drew nearer, he saw that it was the young girl who had come to drink with them the evening before. He remembered her name and called to her, "Xiao Qing, what are you doing up here this early on your own?" Motionless, she continued to sit there on the short grass of the hillside.

"They told me your mum died when you were little. Is that right?" He asked her, breathless by now, his gaze fixed on the iron bracelet on her snow-white wrist.

40 The girl blinked her slanting eyes before she answered. "Yes. She was in a shock brigade of educated youths who were going up the hill to fell some trees for timber, and she slipped and fell halfway up. She was badly hurt, and later on she died".

41 He was astonished, thinking at once of Li Liru. "Your mum-was she from Tianjin?" She gave him a long look, and shook her head. "No-she came from Beijing, her name was Wu Jianrong".

42 Of course, it wasn't unusual then for accidents like that to happen to the young women when they went up into the hills to cut timber. It wasn't only Li Liru who had died that way. Even though he hadn't known Wu Jianrong, he felt sad. Time had raced by, and 
now the orphaned daughter of that young woman had grown up herself, and was working as a hostess in the Halhala valley.

"Who gave you that bracelet you're wearing?"

“It was my mother's. I've been told that in those days you couldn't get anything nice and shiny like gold or silver, you could only get iron, which was black like this".

Deeply touched by what she said, he reached into his pocket and brought out all the notes he had there-more than 600 yuan-thrust them into her hands and walked off. she called after him, but he didn't stop, and hurried down the hillside to the bottom. His stumbling figure looked like a kite with a broken string.

Xiao Qing was now standing up on the side of the hill, screaming after him "Un-cle Edu-cat-ed Youth!" Her cries echoed round the river valley for a long while before they died away.

He stood at the foot of the hill, gasping for breath as he looked around, still hearing her distant cries-“Uncle Educated Youth!"-reverberating through the valley. Up above, the tiny silhouette of Xiao Qing looked to him like a sapling vibrating in the last echoes of the lingering sound. He was suddenly overcome by emotion, and his eyes misted over. Of course, since Xiao Qing's mother had been in the "Educated Youth Brigade", it was only natural for her to call a man who had also been in that group "Uncle Educated Youth". But it was so many years since he had heard that affectionate form of address! It was as if it belonged to another world. Just then, the sun rose, and illuminated both the slender young sapling on the hillside and the purple knife-scar on his left cheek, the scar which was his badge of identity.

He followed a narrow path back to his hut on the bank of the Halhala River. When he got there and saw his precious piece of steel on the doorstep, carefully placed there by Dumb Boy, he smiled. He never worked in the daytime, the daylight hours were for sleeping. He only ever worked in his forge at night, because he believed that the fire in a forge belonged to the darkness and the only possible use for it during the daytime was to make milky tea.

Today, though, he didn't sleep. He was preoccupied, and sat slumped at the door of his hut, listening to the sound of the Halhala River. He was remembering Li Liru, and the two dimples she had when she smiled. She had worn her hair in two short plaits, as all the girls did then. "When she died", he told himself, "that was the picture of her which was engraved on your heart. It won't ever grow old, unlike the rest of us, who are still alive and growing older each and every day, and who will never be fortunate enough to stay the same for all time". Once more, he seemed to see that sapling on the hillside, and he felt very upset.

He let the day pass without lighting his fire, and when dusk fell he went again to the holiday village on the river-bank, looking for his drinking companions of the previous evening. But although it was by now quite dark, nobody had yet appeared in the yurt. He thought this was rather odd, but ordered a bottle of "fire-knife" from the boy who served the drinks and started to drink it on his own. The bonfires outside were beginning to crackle and the atmosphere had a wildness to it which signalled that the night-life was starting up again. The scar on his left cheek was itching, so he got to his feet and went out of the yurt. Far off, the flames of the bonfires were now raging skywards. In the distance he saw a crowd of young girls dancing round one of the fires, so he set off towards them, his bottle in his hand. 
Two burly fellows dressed as security guards suddenly appeared and stood in his way, like a couple of small mountains. They told him the bonfire party wasn't open to "strangers". How ridiculous, he thought-this had always been open land, with no barriers of any sort, and now it had suddenly become a private place where "strangers" were kept out. How things had changed!

Zhang Shu came running up to him, shouting that he should go back to his forge at once and get to work on the sword. He was most amused to see Zhang in such a nervous state. In a low voice, Zhang informed him that $\mathrm{Mr} \mathrm{Mu}$ needed a nice, quiet place for his bonfire party tonight, and no one, repeat no one, was to disturb him.

$\mathrm{Mr} \mathrm{Mu}$ was having a bonfire party? What bonfire party? He asked Zhang, who kept pushing him away, but told him that the "Jade Maiden" was going to be chosen at $\mathrm{Mr}$ Mu's party tonight. "Hurry up! Go home and get to work! You don't want to be late with such an important commission as this".

3 He realised now, from what Zhang had told him, that since Mr Mu's precious sword was to be called "Golden Boy", a "Jade Maiden" had to be chosen as a match for it. He turned and walked away, thinking about this. He pondered it all the way back to his hut, and then suddenly remembered Xiao Qing. Now, knowing that it was Mr Mu who was to choose the Jade Maiden, he became very anxious.

54 Midnight. The flames from the hearth were leaping high. When he saw the steel ingot glowing red in the forge, he knew that the time had come. With metal-working, the knack is to know exactly the right moment to start working the raw material. Dumb Boy stood by the anvil with a large hammer in his hands, waiting to help. His master lifted the steel out of the fire with a pair of tongs and swung it, with a single "heaveho", onto the anvil. Dumb Boy, sensing what his master wanted, brought his hammer down with a yell and started to beat the metal. The clear and melodious sound rang through the whole valley. The blacksmith was chanting to himself as he worked: "Six feet long, four inches wide". As he heated and hammered the steel, then hammered and heated it again, the basic shape of the sword gradually appeared-yes, the temperature of the furnace was perfect. Dumb Boy was getting tremendously excited and kept uttering little cries. The blacksmith was focusing his attention on the half-made sword as it gradually cooled down and turned a deep shade of greenish blue. No blacksmith in the Halhala valley had ever made a sword like this. A good name, "Golden Boy"! The thought made him feel confused again, and Dumb Boy, sensing this, felt obliged to put down his large hammer and start gesticulating and uttering little cries. The blacksmith deliberately ignored him, picked up a lighter mallet and started hammering along the spine of the sword. Extremely agitated by now, Dumb Boy threw down his big hammer and ran off, grunting angrily.

Once again, the blacksmith felt the scar on his left cheek itching, which usually meant that the weather was going to change. The weather in the Halhala valley was as fickle and capricious as a woman. He thought again of Li Liru, of his ex-wife and of every woman he had known. So unlucky, the lot of them!

56 As soon as he closed up the hearth he felt as if the night had grown denser around him. He reached out a hand and touched the blue-green of the embryonic sword-blade. Exactly right-not too cold or too hot, just like the human body. This wasn't a simple piece of metal-it could read your mind. He was glowing with pride from a job well done. In all his years of working in the forge he had never experienced such emotion as 
he did tonight. With an effort, he took the sword in his arms and went into his hut, staggering slightly, as if he was carrying his own child.

Dumb Boy came running back, pushed open the door of the hut and with a series of inarticulate sounds began to try and explain what had happened at the bonfire party that night. The blacksmith, irritated by his slowness, interrupted him and asked who had been chosen as the Jade Maiden. He shook his head to show that he didn't know. The blacksmith was so tormented by anxiety that he started to roar at him, and Dumb Boy backed out of the hut and fled, in panic. The blacksmith lay down inside the hut and went on roaring. "I wanted to know if Xiao Qing was there! That's what I wanted to know!"

The darkness gradually lifted, and the new day arrived. With it came Zhang Shu, accompanied by the two uniformed security guards, to ask how the sword was coming along. The blacksmith walked out of the hut carrying the greenish-blue, semi-finished sword and asked him straight out about the selection of the Jade Maiden at the bonfire party the previous evening. Chuckling, Zhang told him that a total of 120 girls had been whittled down to a short-list of six, that at tomorrow evening's party these six would be narrowed down to two, and at the party on the day after that, one of those two would finally be chosen as the Jade Maiden of the Halhala.

Still cradling the sword-blade in his arms, the blacksmith asked, as casually as he could, whether Xiao Qing had been one of the contestants. "Xiao Qing?" Zhang paused to think. "No, I didn't see her at the party last night".

Immediately he felt relieved. Zhang, looking very serious, reminded him that $\mathrm{Mr} \mathrm{Mu}$ wanted the sword delivered in three days, and if he could manage that he would be remunerated to the tune of 9999 yuan 9 mao and 9 fen instead of 8888 yuan 8 mao and 8 fen.

61 So he'd be paid more-that was good!-but the blacksmith said nothing. Zhang ordered him in a loud voice not to forget to engrave the two characters "Golden Boy" on the sword. He went into his hut, the blue-green sword still in his arms, and they could hear him talking to himself. "The Golden Boy is a sword, made of steel. The Jade Maiden will be a girl, made of flesh and blood, won't she? How can the Golden Boy and the Jade Maiden, steel and flesh, ever be a pair? It wouldn't work. Steel and flesh don't go together, it's impossible".

Outside, Zhang Shu sneered and told him that in pairing the two Mr Mu was promoting and developing China's rich national culture. Foreigners had beauty contests every year, why should China be left behind? "The Jade Maiden is nothing to do with you; my opinion is that you should just get on with finishing the Golden Boy in three days". With these words he tossed a wad of money into the hut through the window, telling him it was the 5000 yuan deposit $\mathrm{Mr} \mathrm{Mu}$ had agreed to.

He lay quietly inside his hut, waiting for nightfall. He never, ever worked his forge in the daytime, no matter how much he was paid. When he had worked in the factory he was often on the night shift, and he had grown to love the sound of metal being worked at midnight, when everyone else was asleep and only he was there to hear it. Now he had heard from Zhang Shu that he hadn't even seen Xiao Qing at the bonfire party last night, he was feeling much easier in his mind. He knew something wasn't right about $\mathrm{Mr} \mathrm{Mu}$ choosing the Jade Maiden. When an old man like that was to choose the Jade Maiden, all was not well. 
focused so entirely on his task that he paid no attention to Dumb Boy, who was itching to take a turn. He reached out a hand for the buffing disc but was swiftly restrained. The blacksmith was not going to allow him to assist in putting the final touches to this work of art.

71 Yes, he was absolutely certain that this sword was the finest thing he had ever made in all his years as a blacksmith. It was clear he had achieved an intimacy between man and metal, and that being the case, it was essential that the blade should be polished until it shone like a mirror, until the light from the edge of it alone could pierce right to the 
human heart. He was conscious that he had fallen in love with the sword, and more than once felt a very strong urge to keep it for his own. He hadn't felt such a depth of emotion since he lost Li Liru. He was so absorbed in oiling the Golden Boy that he completely forgot about the choosing of the Jade Maiden. He oiled the blade and wiped it clean, then he oiled it again, and repeated this ten times. The sword had a blade so sharp that its like had never been seen before, but it possessed other qualities too-the smoothness of jade, the curved sweep of pearls. In creating it, he had achieved the ultimate balance.

He began to wrap the sword in the pale yellow satin, winding the yards of material tightly round and round the six-foot long blade, until only the glittering characters "Golden Boy" were still visible.

On the morning of the third day, Mr Mu dispatched Zhang Shu to collect the sword and deliver the rest of the money he had promised. But the blacksmith, who was usually only too eager to collect his money, wasn't as happy about it this time as he might have anticipated, and he hurried off, saying he wanted to deliver it personally to $\mathrm{Mr} \mathrm{Mu}$. Zhang had no option but to let him.

The sky was growing overcast. Clutching the Golden Boy, wrapped in its yellow satin, he followed Zhang to Kilometre Zero, the place where the main road entered the Halhala valley, and where welcome and farewell ceremonies were held. He was walking into a light breeze, which brought with it the scent of wild roses. All the green grass was standing up, rustling and trembling. He remembered how the grass had been like this when there had been the mass exodus of educated youths from this place, back to the cities.

There were several luxury cars standing at Kilometre Zero, and a crowd of girls holding fresh flowers was already seeing off the honoured guests. The smell of petrol mingled strangely with that of the wild roses. He finally spotted $\mathrm{Mr} \mathrm{Mu}$, wearing a Western-style suit and leather shoes and clearly glowing with satisfaction. The rich old man was standing beside a Japanese-made minibus and waiting for the Golden Boy to be delivered, a picture of benevolence.

The blacksmith walked slowly over to $\mathrm{Mr} \mathrm{Mu}$, and reluctantly held out the Golden Boy to him, feeling as if he were handing him his own son. At this point, all the girls began to cry loudly. The blacksmith felt his own eyes grow wet, and the scar on his face begin to tremble.

$77 \mathrm{Mr} \mathrm{Mu}$ handed the sword to one of his bodyguards, who carried it over to the minibus and put it inside. Zhang Shu, his face wreathed in smiles, said to $\mathrm{Mr} \mathrm{Mu}$, "The Jade Maiden is on board, the Golden Boy is with her, and now you can get in too. I hope you have a very good journey".

78 The Jade Maiden was in the minibus? The blacksmith suddenly realised that something was amiss, and strode over to the bus. Through the window he saw a snow-white arm, wearing the black iron bracelet.

79 What had happened? He dashed across to the group of girls who were seeing the visitors off and screamed at them, "Is the Jade Maiden Xiao Qing? Is it really Xiao Qing?"

80 The girls wept even more loudly. One of them, who had very big eyes, said to him, between sobs, "Xiao Qing is so lucky! In the end it was her they chose, and she's going to the city with one of the 'big bellies'. She's on her way to Paradise!" 
81 He was stunned, and his scar was trembling violently. Abruptly, he turned and sprinted over to the minibus, shouting "Xiao Qing! Xiao Qing!" The minibus started up, and he chased after it, by now almost screaming. "Xiao Qing, leave me your bracelet! Leave me your bracelet!"
He ran after the minibus as fast as he could. As it gathered speed, something flew out of the window and slowly fell to the ground. It was the iron bracelet.

\section{NOTES}

1. During the 1950s, the government of the PRC required students, cadres, soldiers etc. to have "red (i.e. loyal and patriotic) hearts" and to be willing to serve the motherland in whatever capacity was needed. Many young people were assigned to the countryside in the north, and later-in the 1960s-to Xinjiang, Qinghai and Inner Mongolia too. See Wushi nian liuxing ciyu 1949-1999 (Fifty years of terms in popular use, 1949-1999), Shandong jiaoyu chubanshe, 1999).

2. Pičaq, a Uyghur word for "knife".

3. The word hua, "flower" can also refer to prostitutes.

4. The number eight is traditionally seen as lucky in Chinese society. 8,888 yuan is about 1,200 US dollars.

5. Golden Boy and Jade Maiden: in Daoism, these are servants of the Immortals. The term "Jade Maiden" is also used to refer to a pretty young girl.

\section{INDEX}

Thèmes : Art, Culture, Litterature 